\title{
OPTIMASI VEHICLE ROUTING PROBLEM (VRP)DENGAN PENDEKATAN METAHEURISTIK(STUDI KASUS DISTRIBUSI BAHAN BAKU MAKANAN)
}

\author{
Iwan A. Soenandi, Budi Marpaung, Meriastuti Ginting \\ Program Studi Teknik IndustriUniversitas Kristen Krida Wacana, \\ e-mail: Iwan.as@ukrida.ac.id, Budi.marpaung@ukrida.ac.id, meriastuti.ginting@ukrida.ac.id
}

\begin{abstract}
ABSTRAK
Tujuan dari makalah ini adalah untuk merancang sebuah solusi dari permasalahan rute kendaraan dalam mendistribusikan bahan dengan menggunakan perbandingan 4 jenis algoritma metaheuristik yaitu: Algoritma Genetika (GA), Particle Swarm Optimization (PSO), Ant Colony Optimization (ACO) dan Cross Entropy (CE) dengan beberapa kombinasi parameter yang digunakan untuk menjalankan algoritma. Kami menggunakan studi kasus masalah routing dari perusahaan distribusi dalam mendistribusikan bahan baku pada outletoutletnya, yang memiliki 10 node (outlet),dengan menggunakan data dari posisi node dan tingkat lintasan (waktu kedatangan pada node).Hasil dari 4 (empat) algoritma ditemukan bahwa GA, PSO dan ACO memiliki nilai optimasi yang lebih baik daripada iterasi CE dan membutuhkan lebih banyak sumber daya untuk waktu komputasi. Dalam kesimpulan akhir diperoleh waktu komputasi paling cepat adalah CE, sedangkan waktu komputasi paling lambat adalah GA, waktu yang memungkinkan untuk distribusi per hari \pm 6 jam ditetapkan jumlah kendaraan yang dibutuhkan sebanyak 3 unit, dengan total jarak $60 \mathrm{~km}$ dan total waktu 6 jam (kecepatam rata-rata $10 \mathrm{~km} / \mathrm{jam}$ ).
\end{abstract}

Kata kunci:Vehicle Routing Problem, Metaheuristic, Optimasi

\begin{abstract}
The purpose of this paper is to design a solution of vehicle routing problems in distributing material by using a ratio of 4 kinds of metaheuristic algorithms, namely: Genetic Algorithm (GA), Particle Swarm Optimization (PSO), Ant Colony Optimization (ACO) and the Cross Entropy $(C E)$ with several combinations of the parameters used to run the algorithm. We use the case study of a routing problem in a distribution company distributes raw materials in the outlet-outlet, which has 10 nodes (outlet), using data from the node position and trajectory levels (arrival time on the node). Results of 4 (four) algorithm was found that GA, PSO and $A C O$ have a better value than the optimization iterations $C E$ and require more resources for the computing time. In the final conclusions derived fastest computing time is $C E$, while the computing time is later than the GA, which allows for the distribution of time per day \pm 6 hours stipulated number of vehicles needed 3 units, with a total distance of $60 \mathrm{~km}$ and a total time of 6 hours (speed an average of $10 \mathrm{Km} / \mathrm{hour}$ ).
\end{abstract}

Keyword: Vehicle Routing Problem, Metaheuristic, Optimization

\section{PENDAHULUAN}

Penelitian ini pada dasarnya bertujuan untuk menemukan pengaruh jumlah 'node' pada problem TSP terhadap nilai solusi optimal dan waktu komputasi dalam studi kasus perusahaan distribusi makanan ke outlet di mall. Adapun Bagan Rancangan Penelitian dinyatakan dalam Gambar 1. Pada awalnya dilakukan cluster problem VRP, hingga didapat sebanyak k-kluster. Hasil yang diperoleh untuk sebanyak k-cluster problem VRP selanjutnya diolah dan dianalisis. Variabel independen penelitian ini adalah jumlah node, ada sebanyak k buah jumlah variabel bebas. Sedangkan variabel dependen ada dua, yaitu nilai solusi optimal dan waktu komputasi. Pendekatan ini didesain untuk memecahkan masalah dengan mengutamakan waktu komputasi yang relatif lebih singkat dan secara bersamaan memperoleh solusi optimal atau solusi yang mendekati optimal dengan kasus yang serupa dengan TSP namun dengan sedikit modifikasi yaitu VRP. Beberapa metode dalam pendekatan metaheuristik yang berkembang dan dapat digunakan untuk berbagai jenis masalah optimisasi kombinatorial diantaranya Genetic Algorithm(GA), Cross Entropy (CE), Particle Swarm Optimization (PSO) dan Ant Colony Optimization (ACO). 
Pemodelan masalah yang digunakan dalam penelitian ini adalah menghubungkan posisi lokasi titik pengiriman dengan mencari jarak yang optimal yang harus ditempuh oleh kendaraan pengirim. Yang akan dibandingkan dengan beberapa metode algoritma. Penelitian ini mencoba untuk menemukan rujukan atau guidance dalam menentukan metode yang sebaiknya digunakan untuk mengatasi masalah tsp yang akan diterapkan pada penentuan rute distribusi bahan baku makanan ke mall yang ada di jakarta. Penelitian akan mencoba untuk merumuskan hubungan antara tingkat kompleksitas permasalan VRP, yang dinyatakan dalam jumlah 'node' problem, dengan nilai solusi yang diperoleh dan waktu komputasi. Hasil penelitian diharapkan dapat memberikan rekomendasi metode yang sebaiknya digunakan untuk untuk berbagai nilai 'node' problem VRP.Ukuran kluster problem TSP dalam hal ini dinyatakan dalam jumlah node.

\section{TINJAUAN PUSTAKA}

Permasalahan dunia industri dan jasa yang tergolong optimisasi kombinatorial diantaranya penjadwalan produksi, crew scheduling, penjadwalan proyek, traveling salesman problem (TSP), vehicle routing problem (VRP), letak fasilitas dan problem reorienting[1]. Salah satu keunikan optimisasi kombinatorial adalah munculnya berbagai macam metode dengan karakteristik yang berbeda-beda. Hampir semua metode pada optimisasi kombinatorial pada awalnya dikembangkan untuk satu jenis problem, walaupun dalam perkembangan berikutnya ternyata metode tersebut bisa digunakan untuk jenis problem lainnya[2]. Salah satu pendekatan yang paling populer untuk menemukan solusi optimal dalam optimasi kombinatorial adalah pendekatan metaheuristik seperti pada aplikasi Travelling Salesmen Problem (TSP) [3].

Penemuan solusi dengan nilai optimum dan waktu komputasi yang relatif singkat merupakan kondisi paling ideal dalam bidang optimisasi, termasuk pada jenis model optimisasi kombinatorial. Untuk problem yang sama maka masing-masing metode dapat memperoleh nilai solusi optimal yang berbeda dan waktu komputasi yang berbeda pula. Short program Matlab yang dikembangkan untuk Metode GA, CE, PSO, ACO kemudian dirunning untuk setiap k-cluster node VRP, dan diperoleh hasil berupa nilai solusi optimal dan waktu komputasi[4]

Algoritma Genetika merupakan teknik optimasi yang terinspirasi dari prinsip genetika dan seleksi alam, sebagaimana dinyatakan dalam Teori Evolusi oleh Darwin. Algoritma ini digunakan untuk mendapatkan solusi yang tepat untuk masalah optimasi multi-variabel. Berbeda dengan teknik pencarian konvensional, Algoritma Genetika bermula dari himpunan solusi yang dihasilkan secara acak. Himpunan ini disebut populasi. Sedangkan setiap individu dalam populasi disebut kromosom yang merupakan representasi dari fungsi fitness yang akan dicari nilai optimasinya [5]. berikut.

Adapun langkah-langkah dalam Algoritma PSO untuk Clustering[6], sebagai

1) Pendefinisian pusat cluster awal

Yaitu menentukan posisi titik awal sebagai pusat klaster data sebanyak k titik data secara random.

2) Pengelompokan data ke dalam cluster

Data dimasukkan ke dalam salah satu cluster yang mempunyai pusat cluster terdekat dengan data tersebut. Besar kecilnya nilai jarak sangat menentukan letak data tersebut dalam cluster.Penghitungan jarak antara data ke pusat cluster dapat menggunakan rumus jarak Euclidean.Nilai jarak dapat dicari dengan menggunakan konsep jarak lainnya, diantaranya Manhattan, Minkowski, Chebyshev, dan Mahalanobis. Namun demikian konsep jarak yang lebih umum digunakan adalah perhitungan jarak dengan rumus Euclidean. Perhitungan jarak pada algoritmaPSO dilakukan untuk masing- 
masing data ke setiap pusat cluster. Jika terdapat $\mathrm{N}$ data dan $\mathrm{k}$ pusat cluster maka akan dihasilkan sebanyak ( $\mathrm{N} \mathrm{x} \mathrm{k)}$ perhitungan jarak. Selanjutnya, dari hasil perhitungan jarak data dengan pusat clusterakan dicari nilai minimum untuk masing-masing data. Nilai minimum menunjukkan bahwa data lebih dekat dengan pusat cluster sehingga data akan lebih tepat ditempatkan kedalam klaster tersebut.

3) Perhitungan nilai Sum of Squared-Error (SSE)

SSE diterjemahkan sebagai penjumlahan nilai kuadrat dari jarak data dengan pusat cluster. Dalam penelitian ini, SSE merupakan fitness function yang akan dicari nilainya dalam algoritma clustering. Nilai SSE inilah yang akan dicari nilai optimalnya (minimum) dengan menggunakan algoritma PSO.

4) Optimasi clustering dengan PSO

Dalam algoritma PSO Clustering penelitian ini, pusat cluster mewakili partikel. Set solusi yang diperoleh adalah pusat cluster yang baru, yang diharapkan akan menghasilkan perhitungan SSE yang lebih kecil daripada SSE sebelumnya. Sebelum memulai optimasi clustering untuk iterasi awal perlu didefinisikan terlebih dahulu kecepatan awal partikel $\left(\mathrm{V}_{0}\right)$, dengan memperhatikan batas kecepatan. Jika nilai $\mathrm{V}_{0}$ lebih besar dari batas maksimum atau lebih kecil dari batas minimum, maka nilai kecepatan ditetapkan sama dengan batas. Dalam Algoritma PSO.Clustering pada penelitian ini, nilai rata-rata yang digunakan adalah nilai rata-rata terbaik dari semua solusi, karena bukan mencari nilai optimal, namun untuk tujuan pengelompokkan data ke tiap klaster dengan memperhitungkan nilai terbaik dari semua data. Langkah selanjutnya adalah meng-update posisi pusat cluster dengan cara menjumlahkannya dengan nilai kecepatan. Setelah pusat cluster secara random di-update, maka akan diperoleh k titik pusat cluster yang baru. Untuk setiap pusat cluster dilakukan tahapan langkah (2) dan langkah (3), sehingga diperoleh nilai SSE dan cluster terbaik untuk tiap-tiap data.

5) Meng-update nilai SSE

Nilai SSE yang diperoleh paling akhir kemudian dibandingkan dengan nilai SSE sebelumnya. Jika nilai SSE tersebut lebih kecil dari nilai SSEsebelumnya, maka pusat cluster yang dihasilkan akan menjadi pusat cluster yang baru.

6) Pengulangan ke langkah (4)

Pengulangan dilakukan sampai terjadi stopping condition, yaitu setelah beberapa kali iterasi sesuai yang telah ditentukan sebelumnya.

Adapun parameter PSO yang digunakan pada penelitian ini dapat dilihat pada Tabel 3.

\section{Metode Ant Colony Optimization (ACO)[7]}

Ant Colony Optimization(ACO) dikembangkan oleh Dorigo yang terinspirasi dari hasil percobaan mengenai tingkah laku dari koloni semut.Percobaan yang dilakukan adalah mendapatkan tingkah laku dari koloni semut ketika mencari jalan dari sarangnya ke sumber makanan.Dua buah cabang dari sarangnya ke sumber makanan dibedakan dari panjang jalannya.Pada periode tertentu setelah semut melalui kedua percabangan jalan itu, mereka berhasil menemukan jalan terpendek dari kedua jalan tersebut.Tingkah laku semut untuk mencari jalan terpendek merupakan hasil dari sebuah komunikasi secara tidak langsung yang kita ketahui sebagai Stigmergy.Stigmergydidefinisikan sebagai sebuah metode komunikasi pada sistem desentralisasi, dimana setiap individu memodifikasi lingkungan mereka dalam berkomunikasi.Pada kasus semut mencari makanan, semut merubah lingkungan mereka dengan memberikan tanda-tanda kimiawi, yang dikenal sebagai pheromones, disepanjang jalandari jembatan yang dilalui. Menurut Dorigo, dengan merasakan jumlah dari pheromones yang diberikan sepanjang jalan tersebut, maka setiap 
semut dapat membuat keputusan berdasarkan kemungkinan, dipengaruhi oleh jumlah pheromoneyang terdeteksi, cabang mana yang harus dipilihpheromonetersebut.

\section{Teknik Pengumpulan dan Pengolahan Data}

Hasil yang diperoleh untuk setiap jumlahnode VRP selanjutnya ditabulasi dalam sebuah lembaran yang memuat seluruh data. Tabulasi data berisi jumlah node, hasil solusi optimal dan waktu komputasi untuk masing-masing metode. Data ini selanjutnya diolah dan dibuat dalam gambar/chart. Salah satu keunikan berbagai metode dengan pendekatan metaheuristik adalah hasil yang diperoleh untuk setiap running program bisa berbeda, baik nilai maupun waktu komputasi. Dengan melakukan running sebanyak n kali, maka akan diperoleh rata-rata nilai optimal dan waktu komputasi untuk masing-masing metode pada cluster jumlah node yang sama

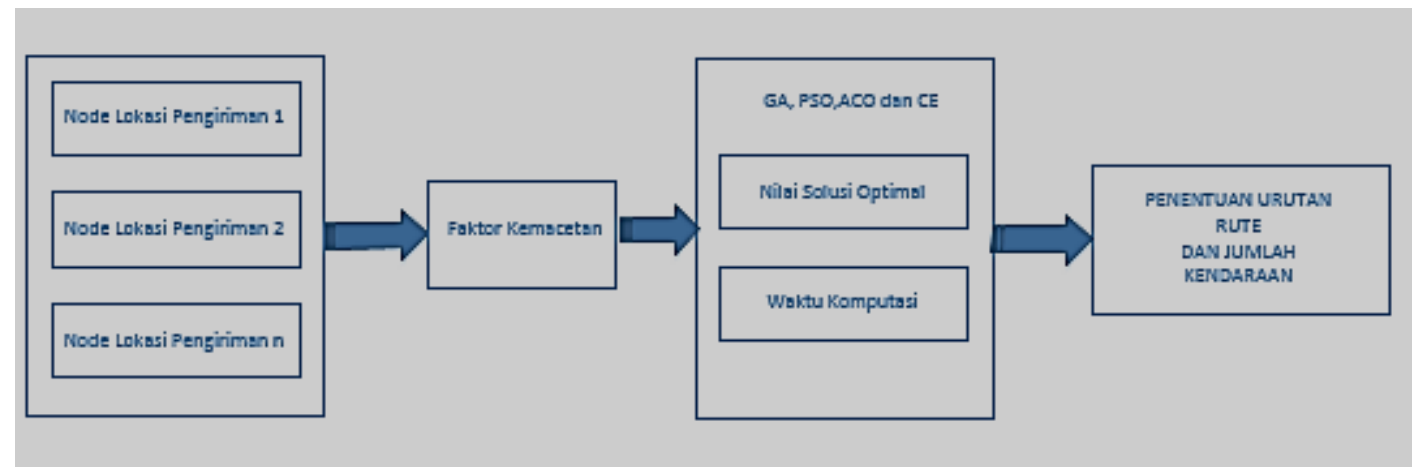

Gambar 1.Bagan Rancangan Penelitian

\section{Pemilihan Obyek Studi Kasus}

Penerapan metode metaheuristik membutuhkan adanya kemungkinan solusi yang sangat banyak, yang memungkinan munculnya kombinasi solusi yang sangat banyak. Penelitian ini menetapkan objek studi kasus pada distribusi bahan baku makanan dari satu depot ke sejumlah outlet di Jakarta. Berdasarkan hasil survey yang dilakukan maka terdapat 10 outlet yang tersebar di sejumlah titik di Jakarta. Setiap pengiriman barang dari depot ke sejumlah outlet membutuhkan dua jenis sumber daya, yaitu manusia dan kendaraan.

\section{Variabel Fungsi Objektif}

Untuk melakukan analisa dengan metode Metaheuristik, variabel fungsi objektif adalah sekumpulan nilai matriks yang menggambarkan hubungan antara satu titik dengan titik lainnya. Nilai matriks tersebut dapat berupa koordinat, jarak ataupun nilai lain yang dapat mewakili posisi titik yang akan dianalisa. Penelitian ini menggunakan data koordinat posisi ditentukan dengan bantuan alat Global Positioning System (GPS). Adapun data posisi sejumlah outlet berdasarkan GPS dinyatakan dalam Tabel 1.

Tabel 1.Posisi Outlet berdasarkan GPS

\begin{tabular}{ccccc}
\hline Kode & & Nama Mall & \multicolumn{2}{c}{ GPS } \\
\cline { 3 - 4 } & & & Latitude & Longitude \\
\hline 1 & A & Mall Kelapa Gading & $-6,157206$ & 106,90771 \\
2 & B & Mall Arta Gading & $-6,145463$ & 106,89182 \\
3 & C & Mall Bekasi & $-6,256226$ & 106,98936 \\
4 & D & Mall Citraland & $-6,168726$ & 106,78738 \\
5 & E & Mall Alam Sutra & $-6,244340$ & 106,65179
\end{tabular}




\begin{tabular}{ccccc}
6 & F & Mall of Indonesia & $-6,151403$ & 106,89147 \\
7 & G & Emporium Pluit & $-6,127919$ & 106,79189 \\
8 & H & Mall Cetral Park & $-6,177193$ & 106,79072 \\
9 & I & Gajah Mada Plaza & $-6,160150$ & 106,81756 \\
\hline
\end{tabular}

FORM DATA PENELITIAN METAHEURISTIK JALUR DISTRIBUSI KENTANG

NAMA SOPIR
JENIS KENDARAAN :BOX/MINIBUS/MOTOR
\begin{tabular}{|c|c|c|c|c|c|}
\hline RUTE & JAM BERANGKAT & JAM TIBA & Kilometer Berangkat & Kilometer Tiba \\
\hline & & & & \\
\hline & & & & & \\
\hline & & & & & \\
\hline & & & & & \\
\hline & & & & & \\
\hline & & & & & \\
\hline & & & & & \\
\hline & & & & & \\
\hline
\end{tabular}

\begin{tabular}{|rrrrrrrrrr|}
\hline 0 & 2 & 14 & 12 & 27 & 2 & 12 & 12 & 9 & 11 \\
2 & 0 & 16 & 11 & 28 & 1 & 10 & 11 & 8 & 11 \\
14 & 16 & 0 & 27 & 34 & 14 & 36 & 21 & 20 & 18 \\
12 & 11 & 27 & 0 & 16 & 11 & 4 & 1 & 3 & 6 \\
27 & 28 & 34 & 16 & 0 & 26 & 18 & 15 & 19 & 16 \\
2 & 1 & 14 & 11 & 26 & 0 & 10 & 10 & 10 & 10 \\
12 & 10 & 36 & 4 & 18 & 10 & 0 & 5 & 4 & 10 \\
12 & 11 & 21 & 1 & 15 & 10 & 5 & 0 & 10 & 5 \\
9 & 8 & 20 & 3 & 19 & 10 & 4 & 10 & 0 & 6 \\
11 & 11 & 18 & 6 & 16 & 10 & 10 & 5 & 6 & 0 \\
\hline
\end{tabular}

Gambar 2.Matrix Jarak+Penalti Kemacetan

Kondisi kemacetan di Jakarta membuat data jarak yang digambarkan oleh koordinat GPS kurang tepat untuk menggambarkan secara nyata(riil) hubungan satu posisi dengan posisi lain. Karena dalam kenyataannya pada situasi di perkotaan yang padat, jarak yang dekat juga harus ditempuh dengan waktu yang relatif lama. Atas pertimbangan tersebut maka penelitian ini mempertimbangkan faktor kemacetan dalam menentukan hubungan antara titik outlet. Untuk mendapatkan data waktu tempuh diperoleh dengan cara meminta sopir kendaraan mengisi form seperti pada Gambar 3.

\section{Penentuan Matrix Jarak dengan Penalti Kemacetan}

Dengan menggabungkan informasi posisi GPS dan waktu tempuh kendaraan sebagai nilai tambahan untuk faktor kemacetan, maka didapatkan matriks baru yang sudah, dengan menambahkan faktor kemacetan lalu lintas di dalamnya. Adapun data matrik jarak dan pinalti kemacetan dinyatakan dalam Gambar 4.

\section{Metode Algoritma Genetik}

\section{HASIL DAN PEMBAHASAN}

Parameter yang digunakan pada penelitian ini dapat dilihat pada Tabel 2.

Tabel 2. Parameter Algoritma Genetik Yang Digunakan

\begin{tabular}{ll}
\hline Populasi & 1000 \\
\hline Probabilitas CrossOver & 0,3 \\
Probabilitas Mutasi & 0,1 \\
\hline Jumlah Iterasi & $100,200,300,500$ \\
\hline
\end{tabular}

\section{Metode Particle Swarm Optimization (PSO)}


Algoritma PSO Clustering pada penelitian ini digunakan untuk proses clustering data dan proses penemuan pusat klaster terbaik. Beberapa input dalam Algoritma PSO Clusteringdiantaranya populasi data yang akan di-cluster-kan, jumlah cluster (k), dan jumlah iterasi yang diinginkan.

\begin{tabular}{|c|c|}
\hline Jumlah swarm (n) & $50,100,200,400$ \\
\hline Dim & 2 \\
\hline $\mathrm{C} 2$ & 1.2 \\
\hline $\mathrm{C} 1$ & 0.12 \\
\hline Momentum (W) & 0.9 \\
\hline
\end{tabular}

\begin{tabular}{cc} 
Tabel 4.Parameter ACO Yang Digunakan \\
\hline Banyaknya Semut (m) & $200,500,1000$ \\
\hline Koefisien Evaporasi (e) & 0.3 \\
$\alpha$ & 0.2 \\
$\beta$ & 0.1 \\
el & 0.3 \\
\hline
\end{tabular}

\section{Metode Cross Entropy}

Pada penelitian ini prinsip-prinsip metode Cross Entropy (CE) yang digunakan berdasarkanliteratur yang diperoleh beserta referensinya. Metode CE diawali denganalgoritma adaptive untuk mengestimasi probabilitas dari rare-event pada jaringan stokastik yang kompleks,yang melibatkan minimasi standar deviasi.Ide utama dari metode CE untuk optimasi dapat dinyatakan sebagai berikut. Misalnya terdapat suatu masalah untuk memaksimasi kinerja fungsi $\mathrm{S}(\mathrm{x})$ pada setiap $\mathrm{x}$ di dalam kumpulan $\chi$ dimananilai maksimum yang didapat adalah $\gamma^{*}$. Pada tahap pertama, masalah deterministik dirandomisasi dengan mendefinisikan robability density function (pdf).Diasumsikan pdf memiliki densitas yang berdegenerasi pada $\mathrm{x}^{*}$, Dalam hal ini $\mathrm{X}$ adalah vektor random dengan pdf.

Tujuan algoritma $\mathrm{CE}$ adalah untuk menghasilkan urutan solusi $\{(\gamma \mathrm{t}, \mathrm{vt})\}$, yang memusat dengancepat ke arah solusi optimal $\left(\gamma^{*}, \mathrm{v}^{*}\right)$. Sebagai awalnya, $\mathrm{v}_{0}$ harus ditetapkan, dan $\rho$ yang tidak terlalu kecil dipilih, misalnya $\rho=0.01$. MetodeCE melibatkan prosedur iterasi, dimana tiap iterasi dapat dipecah menjadi dua fase, yaitu:

1) Melakukan generatesampel data random $(\chi)$ berdasarkan mekanisme spesifik.

2) Memperbaharui parameter (v) dari mekanisme random berdasarkan data sampel elite untuk menghasilkan sampel yang lebih baik pada iterasi berikutnya.

\begin{tabular}{cc} 
Tabel 5.Parameter Cross Entropy Yang Digunakan \\
$\mathrm{N}$ & $100,200,500$ \\
\hline Rho & $0.01,0.02$ \\
$\alpha$ & $0.1,0.3 .0 .5,0.8$ \\
$\mathrm{~A}$ & Matrix Jarak (Koordinat) \\
\hline
\end{tabular}

Keempat metode yang digunakan pada penelitian ini menggunakan parameter sebagaimana dinyatakan di atas, untuk kemudian dibandingkan proses dan hasilnya dengan menggunakan bantuan komputer. Adapun nilai optimal untuk masing-masing metode dan waktu komputasi dinyatakan dalam Tabel 6. Terlihat bahwa terdapat perbedaan nilai optimal untuk keempat metode. Solusi optimal yang diperoleh untuk keempat metode berada pada kisaran 82 sampai 84. Terlihat bahwa nilai optimal CE cenderung stabil, yang diperoleh dengan jumlah iterasi yang relatif kecil. Adapun metode GA, PSO dan ACO memperoleh solusi optimal dengan jumlah iterasi yang relatif jauh lebih besar 
dibandingkan Metode CE. Dengan demikian terlihat bahwa CE cenderung lebih mudah mendapatkan solusi optimal dibandingkan GA, PSO dan ACO. Namun solusi terbaik sebesar 82 justru diperoleh oleh metode GA, PSO dan ACO pada jumlah iterasi hingga 500, dimana CE hanya mendapatkan nilai optimal sebesar 83 pada iterasi 12.

Tabel 6. Perbedaan Hasil GA, PSO, ACO dan CE

Dengan menggunakan $\mathrm{N}=200$

\begin{tabular}{|c|c|c|c|c|c|c|c|c|c|c|c|c|}
\hline \multirow[t]{3}{*}{ Iterasi } & \multicolumn{3}{|c|}{ GA } & \multicolumn{3}{|c|}{ PSO } & \multicolumn{3}{|c|}{$\mathrm{ACO}$} & \multicolumn{3}{|c|}{$\mathrm{CE}$} \\
\hline & \multicolumn{3}{|c|}{$\alpha$} & \multicolumn{3}{|c|}{$\alpha$} & \multicolumn{3}{|c|}{$\alpha$} & \multicolumn{3}{|c|}{$\alpha$} \\
\hline & 0,1 & 0,5 & 0,8 & 0,1 & 0,5 & 0,8 & 0,1 & 0,5 & 0,8 & 0,1 & 0,5 & 0,8 \\
\hline 8 & & & & & & & & & & 84 & & \\
\hline 12 & & & & & & & & & & & 83 & 83 \\
\hline 100 & 110 & 90 & 85 & 120 & 110 & 90 & 103 & 100 & 104 & & & \\
\hline 300 & 95 & 88 & 84 & 105 & 100 & 95 & 90 & 88 & 88 & & & \\
\hline 500 & 90 & 92 & 82 & 90 & 82 & 84 & 87 & 82 & 84 & & & \\
\hline $\begin{array}{c}\text { Waktu } \\
\text { Komputasi } \\
\text { (detik) }\end{array}$ & 120 & 150 & 180 & 120 & 160 & 190 & 110 & 130 & 150 & 10 & 12 & 12 \\
\hline
\end{tabular}

Berdasarkan hasil pada Tabel 6 maka dilakukan analisis kinerja keempat metode, sebagaimana dinyatakan dalam Tabel 7. Pada aspek algoritma terlihat bahwa CE merupakan algoritma yang sangat ringkas dibandingkan GA, PSO dan ACO. Adapun GA dan PSO membutuhkan fungsi fitness dan tidak ada untuk ACO dan CE. CE memiliki iterasi yang sedikit dibandingkan tiga metode lainnya. Adapun jumlah parameter yang dibutuhkan keempat metode cenderung sama. Sedangkan waktu komputasi paling cepat bila menggunakan CE, dan sangat lama bila menggunakan GA. Dari uraian ini terlihat bahwa $\mathrm{CE}$ memiliki sejumlah keunggulan dibandingkan tiga metode lainnya.

Tabel 7. Perbedaan Kinerja Metode Metaheuristik

\begin{tabular}{ccccc}
\hline & GA & PSO & ACO & CE \\
\hline Algoritma & Panjang & Panjang & Panjang & Ringkas \\
Fungsi Fitness & Ada & Tidak Ada & Tidak Ada & Tidak Ada \\
Iterasi & Banyak & Banyak & Banyak & Sedikit \\
Parameter & 4 & 4 & 5 & 5 \\
Waktu & Paling Lama & Lama & Cepat & Paling Cepat \\
\hline
\end{tabular}

Hal berikut yang perlu ditentukan dalam penelitian ini adalah jumlah kendaraan yang sebaiknya dioperasikan ke sejumlah outlet yang tersebar di Jakarta. Dengan memperhatikan jarak dan waktu tempuh, dimana durasi distribusi hingga 6 jam, maka dikembangkan sejumlah alternatif, sebagaimana diuraikan pada Tabel 8 berikut. Terlihat bahwa bila jumlah kendaraan hanya 1 unit, maka waktu yang dibutuhkan 8.2 jam, melebihi waktu yang ditetapkan. Bila jumlah kendaraan ditambah maka waktu dibutuhkan menjadi menurun. Terlihat bahwa jumlah kendaraan paling optimal yang pantas dioperasikan sebanyak 3 unit.

Tabel 8. Alternatif Jumlah Kendaraan yang Diperlukan

\begin{tabular}{cccc}
\hline Jumlah Kendaraan & $\begin{array}{c}\text { Jarak } \\
(\mathrm{Km})\end{array}$ & $\begin{array}{c}\text { Waktu Terlama } \\
(\text { jam })\end{array}$ & Keterangan \\
\hline 1 & $82-83$ & 8,2 & Tidak Memungkinan \\
2 & 70 & 7 & Tidak Optimal \\
3 & 60 & 6 & Optimal \\
\hline
\end{tabular}




\section{KESIMPULAN}

Dari hasil pengolahan data dan analisa dari penelitian ini maka dapat diambil kesimpulan sebagai berikut terdapat pengaruh nilai parameter yang digunakan terhadap hasil perhitungan nilai optimasi dari setiap metode algoritma metaheuristik, setiap metode metaheuristik memerlukan waktu yang berbeda untuk mendapatkan nilai yang paling kecil dalam jarak tempuh. Waktu komputasi paling cepat dalam penelitian ini adalah Cross Entropy (CE), sedangkan waktu komputasi paling lambat adalah Genetic Algorithm (GA), walaupun kondisi yang sebaiknya bisa terjadi untuk kasus yang berbeda, dari waktu yang memungkinkan untuk distribusi per hari \pm 6 jam ditetapkan jumlah kendaraan yang dibutuhkan sebanyak 3 unit, dengan total jarak $60 \mathrm{~km}$ dan total waktu 6 jam (kecepatam rata-rata $10 \mathrm{~km} / \mathrm{jam})$. Masing-masing kendaraan memiliki rute: Daerah 1 meliputi lokasi outlet dalam Kelapa Gading (Minibus), Daerah 2 lokasi outlet di luar Kelapa Gading (Mobil Box), dan Daerah 3 lokasi outlet mall bekasi (Motor). Untuk urutan rute dapat dilihat pada peta Gambar.

\section{DAFTAR PUSTAKA}

[1].Michel, Gendreau \&Potvin, Jean-Yves, 2005,Metaheuristics in Combinatorial Optimization, Annals of Operations Research, Springer Science + Business Media, Inc, Netherlands.

[2].Miftahol, Arifin \& Berlianty Intan, 2010,Teknik-Teknik Optimasi Heuristik, Yogyakarta: Graha Ilmu.

[3].Laporte G., 2010,A concise guide to the Traveling Salesman Problem, Journal of the Operational Research Society, Volume 61, Page 35-40.

[4].Santosa, Budi, \&Paul Willy, 2011,Metoda Metaheuristik: Konsep dan Implementasi.Surabaya: Guna Wydia.

[5].Goldberg, D., 1989, Genetic algorithm in search, optimization and machine learning, Addison-Wesley.

[6].Kennedy, J., Eberhart, R., 1995,Particle Swarm Optimization, Proc. IEEE Int'l. Conf. on Neural Networks (Perth, Australia), IEEE Service Center, Piscataway, NJ, IV: 19421948.

[7].Dorigo, M., \& Gambardella, L., 1996, Ant Colony System: A Cooperative learning Approach to the Traveling Salesman Problem. Tech.Rep/IRIDIA/1996-005, Université Libre de Bruxelles, Belgium.

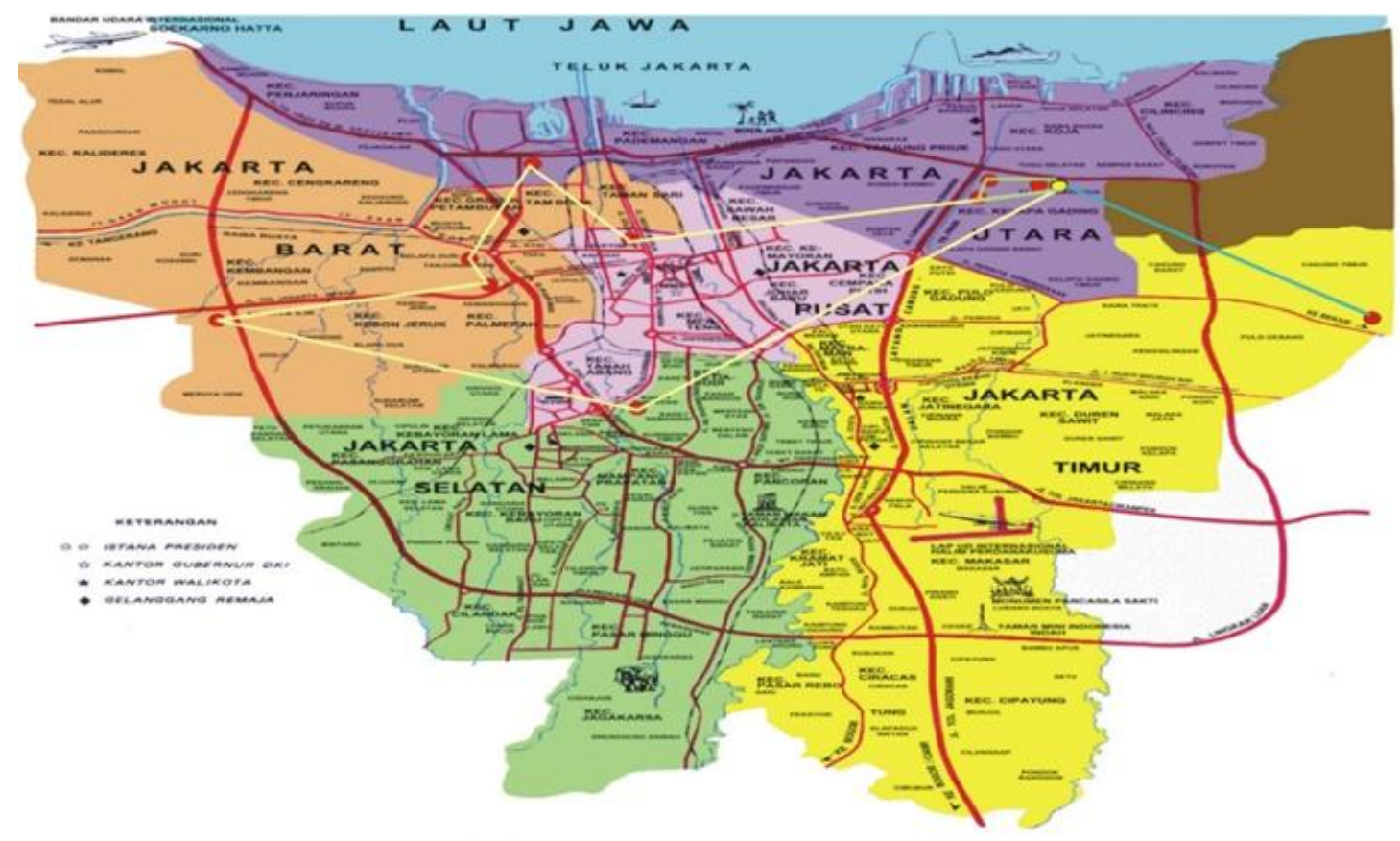


Keterangan gambar peta:

Garis Putih $\rightarrow$ rute mobil box

Garis Kuning $\rightarrow$ rute mobil minibus

Garis hijau $\rightarrow$ rute motor 